\title{
The Anticancer Potential of Pavonia odorata Willd. Extract on Human Breast (MD-MB-231), Prostate (PC-3) and Lung (Calu-6) Cancer cell lines
}

\author{
Girish H V' ${ }^{1}$, Vinod A B ${ }^{1}$, Dhananjaya B L ${ }^{2}$, Satish Kumar D¹ and Senthil Duraisamy ${ }^{1}$ \\ 'Department of Phytochemistry, G7 Synergon Private Limited, Tatanagar, Sahakarnagar Post, Bangalore, India. \\ ${ }^{2}$ Toxinology/Toxicology and Drug Discovery Unit, Centre for Emerging Technologies (CET), Jain University, Kanakpura Taluk, Ramanagara-562112, India.
}

\begin{abstract}
Introduction: A huge reservoir of bioactive compounds exists in many species of plants, only a small percentage of which have been examined and continued to be an important source of anticancer agents. Worldwide effects are ongoing to identify new anticancer compounds from plants. With the current decline in the number of new molecular entities from the pharmaceutical industry, novel anticancer agents are being sought from traditional medicines. Objective: In the present study we investigated the efficacy of methanol extracts of Pavonia odorata, for its clonogenic inhibition on Human Breast cancer (MD-MB-231), Prostate cancer (PC-3) and Lung cancer (Calu-6) cell lines. Materials and Methods: The cytotoxic effect was evaluated by MTT assay. Results: The methanol extract of P. odorata showed significant cytotoxicity against MD-MB-231 and Calu6, when compared to PC-3cells. Conclusion: The methanol extracts of $P$. odorata, showed effective cytotoxic activities in a dose dependent
\end{abstract}

manner. Future work will be interesting to know the chemical composition and also better understanding the mechanism of action will help in developing it as drug for therapeutic application

Key words: Alternative medicine, Anti-cancer, Drugs, Indian Medicinal plants, Inhibition.

Address for Correspondence:

Dr. Girish H V, Department of Phytochemistry, G7 Synergon Private Limited, Tatanagar, Sahakarnagar Post, Bangalore, India.

Official Phone No: 08022172739

E-mail: girish.hv@g7synergon.in

DOI : 10.5530/pj.2016.1.6

\section{INTRODUCTION}

Herbal drugs have been used since ancient times as medicines for the treatment of a range of diseases. Medicinal plants have played a key role in world health. An increasing number of research papers and reviews clearly indicate that medicinal plants exhibit a variety of therapeutic properties ${ }^{1-3}$ and provide health security to the people. In vitro cytotoxicity screening models provide important preliminary data to help select plant extracts with potential antineoplastic properties for further work to develop them into therapeutic leads. As mentioned above, the exploration of nature as a source of new active agents is needed for discovering bioactive chemo-types from natural product for the development and novel molecular diversity of efficacious drugs. In this respect, natural products from plants, used either alone or with combinatorial synthetic methodologies, constitute a multidisciplinary approach to the current drug productivity. ${ }_{4,5}$ This has opened up new fields of investigation of potential antitumor compounds, some of which are already widely used in cancer chemotherapy which act through different pathways in activation of apoptosis in cancer cells leading to cell cytotoxicity.

Pavonia odorata (Malvaceae) is an indigenous medicinal plant of India that is frequently used in Ayurvedic system of medicine as a cooling, diaphoretic, diuretic, and demulcent. ${ }^{6,7}$ In combination with others, it is prescribed as an astringent and tonic for fever, inflammation and haemorrhage. ${ }^{78}$ It has been reported for anti-inflammatory and anti-microbial activities.9 In an earlier study it was shown that the hydro alcoholic fractions of $P$. odorata showed in vitro cytotoxicity against Erlich's ascites carcinoma (EAC) cells. ${ }^{10}$ Further, it was observed that the hydroalcoholic fractions significantly inhibited the ascites tumor in EAC bearing mice.10 As till date, there was no report on its anticancer potential of Pavonia odorata ( $P$. odorata) on other cancer cell lines, henceforth, in this study we have attempted to investigate the in vitro cytotoxic poten- tial of methanolic extract of $P$. odorata on Human Breast cancer (MDMB-231), Prostate cancer (PC-3) and Lung cancer (Calu-6) cell lines.

\section{MATERIALS AND METHODS}

\section{Materials}

All the chemical reagents and solvents of analytical grade were purchased from SRL Chemicals, India. 3-(4, 5- dimethylthiazol-2-yl)-2, 5-diphenyl tetrazolium bromide (MTT, No M5655) purchased from Sigma (St Louis, MO, USA).

\section{PLANT MATERIAL AND EXTRACTS PREPARATION}

\section{Selection of Medicinal plants}

Pavonia odorata Willd. (P. odorata) were collected from Western Ghats and around Mysore. Plant were analyzed for botanical identity, scientific name including genus, species, subspecies or variety and the family of the plant were recorded and verified for taxonomical status, as recommended by the national pharmacopoeia. Further, the plants were identified by a Taxonomist and the voucher specimens (SY-P-52) were kept at G7 Synergon Private Limited.

\section{Preparation of extracts}

P. odorata plant parts were washed with distilled water, dried and crushed into fine powder by using electric grinder. The finely powdered material was extracted with methanol in a Soxhlet apparatus for $24 \mathrm{~h}$. The extract was dehydrated/concentrated under reduced pressure using a rotary flash evaporator (BuchiFlawil, Switzerland) and preserved aseptically at $5^{\circ} \mathrm{C}$ in airtight bottle until further use. ${ }^{11}$ 


\section{In-vitro cytotoxic assays Cell culture assay}

The human carcinoma cell lines, MDA-MB-231, PC 3 and Calu 6 were obtained from American Type culture Collection (ATCC). The cells were grown in DMEM containing $2 \mathrm{mM}$ L-glutamine supplemented with $10 \%$ fetal bovine serum and $100 \mathrm{U} / \mathrm{ml}$ of penicillin-streptomycin. The cells were incubated at $37^{\circ} \mathrm{C}$ in a humidified $5 \% \mathrm{CO}_{2}$ incubator. All the cell lines used in this study were of early passage number.

\section{MTT Assay Cytotoxicity assay}

Cytotoxicity test were carried out using MTT assay. ${ }^{12,13}$ The Trypsinize 70-80\% confluent cell lines (MDA-MB-231, PC 3 and Calu 6) of $1 \times 105$ cells/well are seeded in a 96 well plate and incubate for $24 \mathrm{hr}$ at $37^{\circ} \mathrm{C}$, and varying concentrations $(0-500 \mu \mathrm{g} / \mathrm{ml})$ of $P$. odorata were added. After incubation of different time points, $20 \mu \mathrm{L}$ of MTT reagent were added to each well and incubated for $4 \mathrm{hr}$ at $37^{\circ} \mathrm{C}$. The incubated cells were washed twice with PBS and DMSO $(100 \mu \mathrm{L} /$ well $)$ reagent which dissolved the insoluble crystalline formazan product. The efficacy of the sample was determined based on the reduced dye at $570 \mathrm{~nm}$ by UV spectrophotometer. Doxorubicin at $50 \mathrm{um} / \mathrm{ml}$ was used as a standard and appropriate controls were taken. The effects of the samples on the proliferation of cell lines were expressed as the $\%$ cell viability, using the following formula: $\%$ cell viability $=$ A570 of treated cells / A570 of control cells $\times 100 \%$.

\section{Statistical analysis}

The experiments were carried out in triplicate and results are given as the mean \pm standard deviation. The data in all the experiments were analyzed (Microsoft Excel 2007) for statistical significance using Students $t$-test and differences were considered significant at $\mathrm{p}<0.05$.

\section{RESULTS AND DISCUSSION}

Plants have always been a potential source of new drug molecule and research work in this domain has resulted in discovery of more efficient drugs for cancer treatment. ${ }^{3,5}$ MTT is a simple, reliable technique, which measures cell viability and can be used for screening anti-proliferative agents. ${ }^{12,13}$ MTT assay is a a spectrophotometric analysis, which uses (3-[4,5-dimethyl-thiazol-2-yl]-2,5-diphenyl tetrazolium bromide), known as MTT, a yellow collor and water soluble compound. The MTT enters the cells through the plasma membrane and, in contact with superoxide produced by the mitochondrial activity, is oxidized to MTTformazan, a slat purplish color, which is insoluble in water. Then the oxidation of MTT is proportional to the mitochondrial activity and therefore to cell viability. ${ }^{12,13}$

In the present study, we investigated the efficacy of methanol extracts of P. odorata, for its clonogenic inhibition on Human Breast cancer (MDMB-231), Prostate cancer (PC-3) and Lung cancer (Calu-6). When evaluated at different concentration $(0-500 \mu \mathrm{g} / \mathrm{ml})$ it was observed that in a dose dependent manner the extract of $P$. odorata was effective in inducing cytotoxic effect upon MD-MB-231 (Figure 1), PC-3 (Figure 2) and Calu-6 (Figure 3) cell lines. When compared, the methanol extract of P. odorata exhibited significant cytotoxicity up to $\sim 80 \%$. However, doxorubicin which acted as positive control exhibited up to $\sim 86 \%$. Based on the $\mathrm{IC}_{50}$ values (Table 1), it is observed that the methanol extract $P$. odorata showed significant cytotoxicity against MD-MB-231 and Calu-6, when compared to PC-3cells. Furthermore, it was observed that the control assays that were carried out for samples containing only the appropriate volumes of blank solutions showed no effect on cell growth. In an earlier study it was observed that cytotoxic and antitumor effect was observed for chloroform, ethyl acetate and hydroalcoholic fraction of $P$. odorata against EAC cells. ${ }^{10}$ Further, it was observed that in the

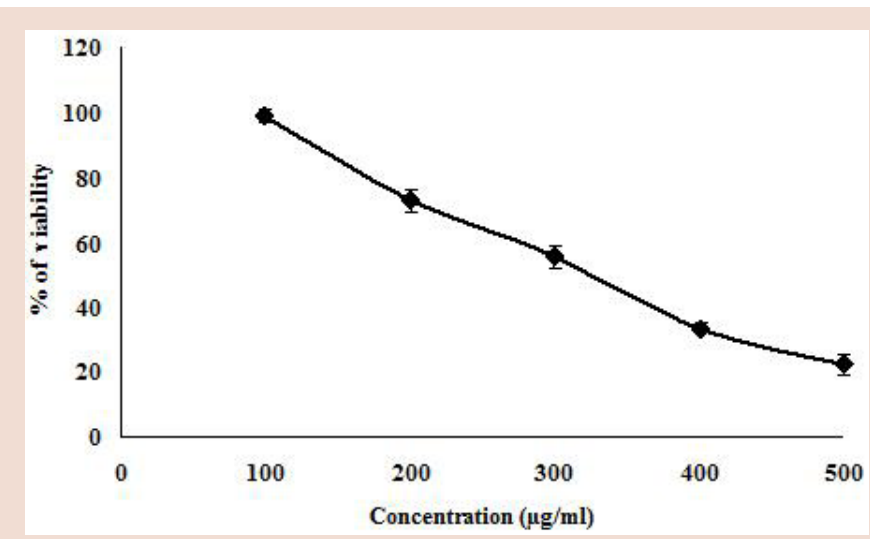

Figure 1: Cytotoxic activity of $P$. odorata methanolic extract on Human Breast cancer (MD-MB-231) cell lines.

Extract were incubated with $10^{5}$ viable cells at concentrations ranging from 0 to $500 \mu \mathrm{g} / \mathrm{ml}$ for $48 \mathrm{~h}$. Cell viability was determined by the MTT method.

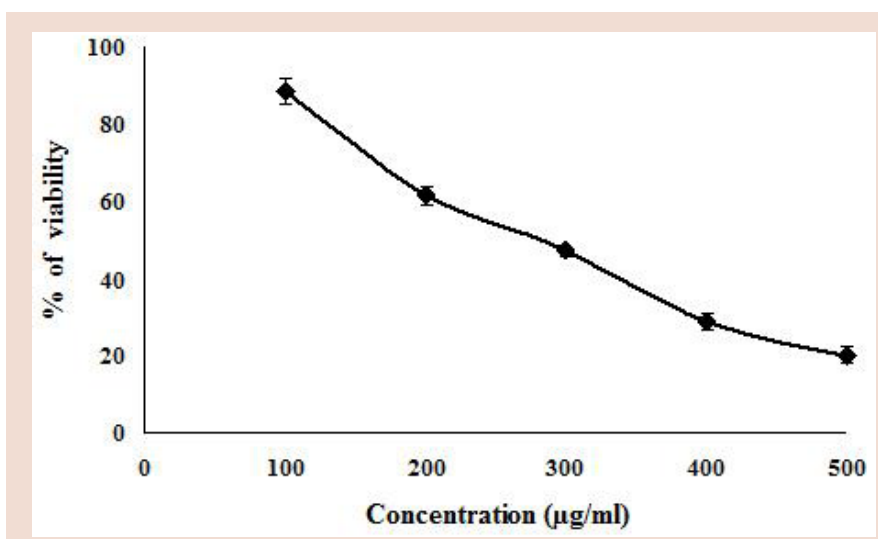

Figure 2: Cytotoxic activity of $P$. odorata methanolic extract on Prostate cancer (PC-3) cell lines.

Extract were incubated with $10^{5}$ viable cells at concentrations ranging from 0 to $500 \mu \mathrm{g} / \mathrm{ml}$ for $48 \mathrm{~h}$. Cell viability was determined by the MTT method.

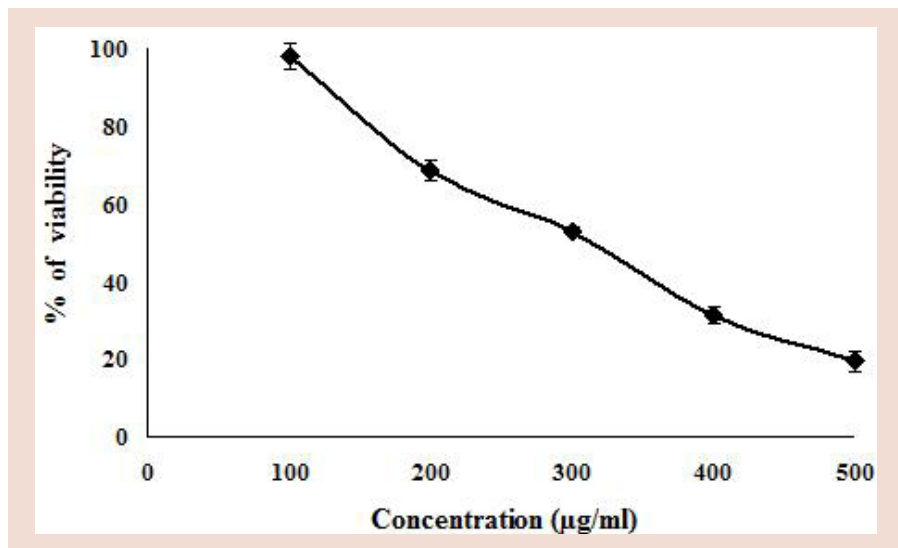

Figure 3: Cytotoxic activity of $P$. odorata methanolic extracts on Lung cancer (Calu-6) cell lines.

Extract were incubated with $10^{5}$ viable cells at concentrations ranging from 0 to $500 \mu \mathrm{g} / \mathrm{ml}$ for $48 \mathrm{~h}$. Cell viability was determined by the MTT method.

in-vivo experiments among the three fractions, hydroalcoholic and ethyl acetate fractions significantly inhibited the ascites tumor in EAC bearing mice after 9 days treatment and the $\mathrm{IC}_{50}$ values were 477.71, 654.57 and $339.20 \mu \mathrm{g} / \mathrm{ml}$ respectively. ${ }^{10}$ 
Table 1: $I C_{50}$ values of methanolic extract of $P$. odarata

\begin{tabular}{cc}
\hline Cell Lines & $\begin{array}{c}\mathrm{IC}_{50} \text { Value } \\
(\boldsymbol{\mu g} / \mathrm{ml})\end{array}$ \\
\hline MD-MB-231 & $315.16 \pm 1.7$ \\
PC-3 & $340.12 \pm 4.2$ \\
Calu-6 & $395.16 \pm 3.7$ \\
\hline
\end{tabular}

Results represent means \pm standard deviation $(n=3)$.

Preliminary phytochemical examination of ethanolic fraction of $P$. odorata has been reported to contain flavonoids and most number of flavonoids are known to possesses remarkable antitumor activity. ${ }^{14} \mathrm{Al}$ though it is most accepted that the clear antitumor mechanism of flavonoids is not well known, they are reported to decrease the high glycolytic activity of tumor cells by inhibition of $\mathrm{Na}^{+}$and $\mathrm{K}^{+}$ATPase in the plasma membrane ${ }^{15}$ and this may be one of the reasons for the inhibition of tumor growth. Similarly in our experiments the observed significant cytotoxic effect on Human Breast cancer (MD-MB-231), Prostate cancer (PC-3) and Lung cancer (Calu-6) by P. odorata extract may be due to the action of flavonoids and other constituents present in the extract. Therefore, it will be interesting to understand the chemical composition and better understand the mechanism of action of the bioactive constituents of the extract for developing it as drug for therapeutic application.

\section{CONCLUSION}

The results of this study indicate anticancer activities for $P$. odorata extract. P. odorata showed significant cytotoxicity against MD-MB-231 and Calu6, when compared to PC-3 cells. The potential anticancer activities of P. odorata extracts may be due to the presence of flavonoids and other constituents. The experimental evidence could be useful for validating the traditional use of plant as source of easily available effective anticancer agents to the people, particularly in developing countries. Future investigations will be interesting to find medicinal compound and also better understanding its mechanism of action against cancer.

\section{ACKNOWLEDGEMENT}

The authors are grateful to Department of Phytochemistry, G7 Synergon Private Limited, and the ICMR for providing financial support. DBL thank Jain University for the constant support and encouragement for carrying out research aspects.

\section{CONFLICT OF INTEREST}

The author declares no conflict of interest.

\section{REFERENCES}

1. Ankli A, Heinrich M, Bork P, Wolfram L, Bauerfeind P, Brun R, et al. Yucatec Mayan medicinal plants: evaluation based on indigenous uses. J Ethnopharmacol. 2002; 79(1): 43-52.

2. Neto CC, Owens CW, Langfield RD, Comeau AB, Onge JS, Vaisberg AJ, et al. Antibacterial activity of some Peruvian medicinal plants from the Callejon de Huaylas. J Ethnopharmacol. 2002; 79(1): 133-8.

3. Sundaram S, Verma SK, Dwivedi P. In vitro cytotoxic activity of indian medicinal plants used traditionally to treat cancer. Asian J Pharm Clinl Res. 2011; 4(1): 27-9.

4. Goh BH, Kadir A. In vitro cytotoxic potential of Swietenia macrophylla King seeds againsthuman carcinoma cell lines. J Med Plants Res. 2011; 5(8): 1395-404.

5. Seham MA, Moustafa A, Menshawi BM, Wassel GM, Mahmoud K, et al. Screening of some Plants in Egypt for their Cytotoxicity against four Human Cancer cell lines. Int J Pharm Tech Res. 2014; 6(3): 1074-84.

6. Shukla VS, Nigam IC. Pavonia odaranta. I. Preparation of resinoids and essential oil and examination of oil-free distillate waters. Proc. Int. Chem. 1961; 33(2): 229-33

7. Kashima Y, Nakaya S, Miyazawa M. Volatile composition and sensory properties of Indian herbal medicne - Pavonia odorata- used in Ayurveda. J Oleo Sci. 2014; 63(2): 149-58.

8. Baslas KK. Essential oil from the roots of Pavonia odaranta. Perfum. Essent. Oil. Rec. 1959; 50(1): 896-7.

9. Rayar A, Aeganathan R, Ilayaraja S, Prabakaran K, Manivannan R. Anti-microbial and Anti-Inflammatory Activity of Bioactive Components of Pavonia odorata Wild. American J Phytomed Clin Ther. 2015; 3(1): 079-87.

10. Selvan VT, Kakoti BB, Gomathi P, Ashok Kumar D, Islam A. Cytotoxic and antitumor activities of Pavinia odorata against Erlichs's ascities carcinoma cells bearing mice. Pharmacology online 2007; 2(1): 453-77.

11. Harborne JB. Phytochemical methods: A guide to modern techniques of plant analysis. 3rd edition Chapman and Hall pub. London.UK; 1998.

12. Mosmann T. Rapid colorimetric assay for cellular growth and survival: application to proliferation and cytotoxicity assays. J Immunol. Methods 1983; 65(1-2): 55-63.

13. Edmondson JM, Armstrong LS, Martinez AO. A rapid and simple MTT-based spectrophotometric assay for determining drug sensitivity in monolayer cultures. J Tissue Cult. Methods 1988; 11(1): 15-7.

14. Carlo GD, Mascolo N, Izzo AA, Capaso F. Flavonoids: old and new aspects of a class of natural therapeutic drugs. Life Sci. 1999; 65(4): 337-53.

15. Pomilio AB, Sola GAR, Mayer AMS, Rumi LS. Antitumor and cytotoxic screen of 5, 6, 7-trisubstituted flavones from Gomphrena martiana. J Ethnopharmacology 1994; 44(1): 25-33. 